\title{
UNEMPLOYMENT AND ANALYSIS OF REAL ESTATE SUPPLY DURING THE 20'S AND 30'S IN CZECHOSLOVAKIA
}

\author{
[Nezaměstnanost a analýza nabídky nemovitostí v průběhu 20 a 30 let v \\ Československu]
}

\author{
David Slavata ${ }^{1}$ \\ ${ }^{1}$ Vysoká škola báňská-Technická univerzita Ostrava, Ekonomická fakulta, Sokolská 33, 70121 Ostrava \\ Email:david.slavata@vsb.cz
}

\begin{abstract}
The paper explains the relationship between the unemployment and structure of supply of the real estate market during the $20^{\prime} \mathrm{s}$ and 30 's of $20^{\text {th }}$ century in Czechoslovakia. There are four segments of the real estate market investigated, such as rental, home ownership, farmhouse and residential buildings. Correlations between the unemployment and rental sector and the farmhouse sector were found out. A certain correlation was discovered even between the farmhouse sector and the residential building sector. In the paper, the reasons of this relationship in conditions of the Czechoslovak real estate market are presented.
\end{abstract}

Keywords: farmhouse sector, home ownership, housing market structure, rental housing, residential buildings, unemployment.

JEL classification: R15, R23, A11

Doručeno redakci: 28.2.2017; Recenzováno: 22.3.2017; 18.4.2017; Schváleno k publikování: 20.9.2017

\section{Introduction}

The paper focuses on the landlord's and tenant's behaviour through the analysis of the housing market structure. We are trying to explain some coherences between the changes of the supply structure of real estates and the development of unemployment. As a sample for the exploration of these relationships, the analysis of data describing the situation of the housing market before and during the Great Depression in the 30's in Czechoslovakia will be presented. Some of sources distinguish (Sekanina 2004) even several phases of great depression in Czechoslovakia, which is agrarian crisis (1928 - 1931), financial crisis (1931 $1933)$ and great depression $(1933-1935)$.

In accordance with a great deal of research on the similar topic developed since the $70 \mathrm{~s}$, I assume that even by analysing the real estate market of Czechoslovakia during the 30 ' $\mathrm{s}$ it is possible to find out the evidence of basic relations between the housing ownership and unemployment.

Numerous research in the field of the structure of the real estate market and unemployment has been conducted. The topic seems to be very important from the macroeconomic point of view. The changes in the structure of real estate supply can indicate the changes in landlords' and tenants' behaviour caused by their expectations. There are many of reasons for such behaviour. The most listed reasons are such as an increase of prices, wages, unemployment, demographic development or political changes.

The main motivation of the author why the real estate market of 20's and 30's is being studied is its relative simplicity compared to the current state. During 20's and 30's there were not so many different segments of real estates. Currantly there are so many different segments with 
many of different ownership rights (flats in ownership for sale, flats in cooperative ownership for sale, commercial spaces for sale etc.), which probably would make the analysis harder.

The next reason consist in stable and sufficient source of real estate data. Advertisements have been printed in daily press for decades, so I could get the informations for more than 80 years at least (I started to collect the data from daily press printed from 1863), which provide an interesting source of data that can be inspected in many of different ways. In comparison to current stage it is more difficult to get the compact data for such long period. It is complicated by the political evants before 1989 as well as wider opportunities for publishing an advertisemnts (internet pages).

And finally there have not been done any real estate analysis in period of 20's and 30's yet. I have not found any related analysis describing the progress of real estate market in selected period.

\section{Literature Review}

In literature, relations especially between the home ownership, rental sector and unemployment have been presented. It seems the relationship between the real estate market and rate of unemployment is highly significant.

Economic and social conditions of Czechoslovakia during 20's and 30's in context of unemployment and housing are analysed by several authors in their bibliographies (Polakova, Rakosnik, Sekanina).

A comprehensive description of the situation in the field of housing during 20's and 30's in Czechoslovakia provides Polakova (2006), who introduces three phases of housing development. The first phase $(1919-1924)$ is characterized by economic fluctuations. From the point of housing supply the lack of flats in the beginning of Czechoslovakia is the most typicall. The second phase (1925 - 1929) is characterized by stable decreasing of quantitative lack of houses. In the years $1930-1938$ housing is influenced by great depression (the third phase), which caused qualitative decrease of housing. Concerns about depreciation of the currency at the end of the period (year 1937, 1938) have increased demand for real estate, so the number of sales and the prices of the real estates have risen.

The tenant protection is typicall for the housing market of 20's and 30's, she introduces. The share of housing costs for working families of its all expenses had risen from $11,7 \%$ (year 1925) up to $17,9 \%$ (year 1938) in Prague. The government subsidized new housing construction as well. The most typicall instruments were tax reliefs, state guarantes, state loans and acceptation of new building law.

Another deep analysis of unemployment and housing market provides Rakosnik (2008), who describes historical context of labour in Czechoslovakia. In his bibliography the specifics of unemployment during the searched period is described. To analyse relationship between unemployment and real estate market the assumption of free movement of labour force is necessary. Compared to previous century, when the equal relationship between employer and employee was not yet common, at the beginning of 20th century, there is already a classical, modern and equitable relationship, he introduces, wich is necessary condition for futher analysis. The modern relationship between amployer and amployee was set in the law in year 1811. In spite of this to reach modern equal relationship it lasted nearly 200 years in Czechoslovak region. 
Oswald, who has been most cited (1999), tries to argue that the main problem of European unemployment is caused by the structural (un)balance of the housing market. The home ownership increases the unemployment rate. The reason for his argumentation are the costs and risks involved in owning a home compared to renting. The less mobility of homeowners causes higher unemployment. He recommends reviving private rental housing as a treatment for reducing unemployment. His surveys show that unemployment rates had risen most quickly in the nations with the fastest growth in home ownership. In his paper, he compares the statistical data from 1990s and 1960s that confirm his arguments.

Hughes and Mc Cormick (1991) in their paper discover the connection between the housing markets and the labour market flexibility. They found some relationships between the labour market flexibility and unemployment by analysing the households migration data from the U.K. and the U.S.

Munch, Rosholm and Svarer (2007) tried to develop the other quality of the relationship between home ownership, job duration and wages in their paper analysing the Danish employment data. By analysing the data they find out that, the home ownership has a negative impact on job - to - job mobility both in terms of transition into new local jobs and new jobs outside the local labor market. They confirm a clear negative effect of home ownership on the unemployment risk and a positive impact on wages.

Ionnides and Zabel (2008) presented the modified point of view. They try to search for the relation between vacant houses and the labour market. They develop the dynamic model of job and housing vacancy rates. In their model, they used the data from the US census. The result of their research, by using the developed model, was the presentation of the negative significant impact on job vacancies in case of the shocks to the owner and rental vacancies.

The advanced literature in the field of housing and labour market is oriented on the use of the housing vacancies as a main searching category. It mostly introduces the changes in housing vacancy rates as a base for measuring the key events. The changes in housing vacancy rates are presented as reaction of landlords to the changing economic situation.

The models based on the concept of the vacancy rate are widely accepted in the academic and professional real estate community. Rosen and Smith (1983) for instance, develop the concept of the structural vacancy rate.

They introduced the structural vacancy rate, which is analogical with the concept of the natural or frictional unemployment rate as a minimum required rate to satisfy the search needs of employers and job seekers. Using the similarity, the structural vacancy rate is the stock that is necessary to stay vacant for some reasons. The first reason to let the vacant flat is the potential for the rent increase in the future. If the landlord expects the increase of the rent which will cover the recent forgone rent at least, than he will make the profit compared to the contemporary stage.

It is possible to express that his marginal benefit (MB) should be greater than his marginal cost (MC).

The next reason why a vacant housing stock should stay is to support the tenant search. If the stock is vacant, from the point of demand it should attract the potential seekers. 
The level of the structural vacant rate depends on the landlord's and tenant's search processes as the literature presents (Wheaton and Torto 1988, Sivitanides 2003).

As the expectations for demand and rental growth will increase the higher the structural vacant rate. In such a situation, the growth of vacant flats is expected. The main reasons for the landlords to accept such a decision would be the growth of employment rates.

On the other side the cost of holding vacant units, motivate the landlords as well. In any time, the landlords compare the value of forgone income in case of holding vacant spaces. In case of higher rents, the forgone rents will be higher and of course, the motivation to hold vacant units will decrease.

\section{Assumptions For the Real Estate Supply Analysis}

In this paper there will be used the mentioned concept of the structural vacant rate for the analysis of the supply structure of the real estate market.

The key question is how to determine the vacant rate. There is a possibility to determine the vacant rate in the real estate market by analysing real estate advertisements. Our assumption is the real estate advertisements reflect the vacancies. If there is a vacant real estate, the motivation of the landlord is to register it in the real estate market to maximize the profit. By studying the old newspapers, it is possible to reconstruct the map of changes in the real estate market during the 20 's and 30 's in Czechoslovakia.

To the best of my knowledge, by studying many of papers, the method of collecting the data using the real estate advertisements has not been used. It is surprising that such an interesting source of data is left unnoticed.

The aim of this paper is to find out whether the relationship exists between unemployment and the rate of offered vacancies under the condition of the Czechoslovak real estate market during the $20^{\prime} \mathrm{s}$ and $30^{\prime} \mathrm{s}$. The relations to the several real estate markets will be inspected. We assume unemployment will influence the level of the vacant rate in specific segments of the real estate market. By analysing advertisements in the contemporary press of the 20's and 30 's the basic segments of the real estate market will be determined, which is the subject to the research.

The segments are:

1. family houses ready for sell,

2. flats ready for rent,

3. residential homes ready for sale,

4. farmhouses ready for sale.

Family houses for sell is the typical real estate segment representing home ownership during the 20's and 30's. In comparison with contemporary situation at the beginning of the 21st century where the typical home ownership is represented mostly by the flats for sell. In comparison to the contemporary situation, we can expect a much more heterogeneous segment of family houses for sell in the 30 's and 20's. Each house can be characterised as unique. Many of differences caused many problems to calculate the real market price. Such an assumption leads me to express that the market price is difficult to determine by the seller. Within the condition of the significant heterogeneous segment, it takes much more time to seek and determine the market price by the seller. Once a market price is determined there are 
plenty of other reasons why the house cannot be sold quickly (see Oswald (1999). Such conditions lead me to the assumption that there is no relationship between the rate of family houses ready for sale and unemployment.

The flats ready for rent. During the 20 's and 30 's of the 20th century the flats ready for rent were the only one alternative how to get the place to live. The main purpose why the flats were offered in the market was to make the profit. Compared to prices of a house, the flat is much more homogenous and the determination of the market rent is not so difficult. Both the landlord and the tenant can easily identify the market price of rent at any time.

What makes the next difference is the lease agreement. The agreement conditions mostly come from civil law of the country. The situation of the tenant of course is less stable in comparison with the homeowner. The change of the economic situation can cause the change of a decision for both sides of the lease agreement.

The rental sector is more dynamic in comparison to the home ownership sector (family houses ready for sale). Because of this, there is an assumption of a significant relationship between flats ready for rent and unemployment.

The theoretical analysis does not address the issue of the farmhouse segment turn too much. The segment of farmhouses ready for sale seems to be an important part of the real estate market during the 20's and 30's. The motivation for sale has not been analysed too much.

We can assume a decrease of supply if the farmers expect the increase of unemployment. It is possible to indicate the negative correlation. The farmhouses ensure the minimal income for their owners, even if the farmer is unemployed.

The residential homes for sale represented the important part of the Czechoslovak real estate market as well. It seems the motivation for sell can be negative when correlated with the comparison of flats ready for rent. If there is not possible to rent a flat (or it is lossy), the landlords will be willing to sell it more. On the other side to sell or not to sell, the residential building can be affected by many other reasons. In case of political changes, the depreciation of currency, residential buildings can save the values.

According to the analysed theories, the research question follows:

1. Does the unemployment affect the share of family houses ready to sell?

2. Does the unemployment affect the share of flat ready for rent?

3. Does the unemployment affect the share of farmhouses ready for sell?

4. Is there any relationship between the searching segments of the real estate market?

To answer the above questions, let us propose a new approach based on the link between the structure of real estate supply (the vacancies ready to offer) and unemployment.

\section{Material and Methods}

The data from 1919 to 1937 were collected from daily press. Lidove Noviny, a daily press, was selected as the main source of data. Lidove Noviny was during the 20's and 30's one of the most demanded daily newspapers. Its edition covered the largest Czech part of the then Czechoslovakia. During the two months of work in the Moravian Land Library 312 newspapers were carefully inspected from which 108 belong to the area of interest of our research. There were all the advertisements regarding the real estate market observed. The 
information was carefully recorded into the software. There was collected at around 5000 valuable information from which 2269 belongs to the area of interest of our research. To reduce the seasonal fluctuation, the data were recalculated as an average in each year.

It was found, the advertisements can be sorted into four basic segment, which is rental, family houses, farmhouses for sale and multiflat buildings for sale segments. In comparison with contemporary stage the real estate market was more simple.

Generally there have been published the advertisements for real estates located mostly in Central Bohemia, occasionally in Moravia. There were nearly no advertisements for real estates located in border regions of Bohemia and Moravia (Sudetes). The other advertisements for real estates located in Slovakia, Ruthenia and abroad were not recorded into database. The advertisements were not sorted by the locality. It would be very difficult to identify some places (villages, cities) because some of their names has been changed or do not exist any more.

The information concerning unemployment from the Czechoslovak Statistical Yearbook 1938 was taken. The information regarding unemployment was properly investigated and recorded by the Czechoslovak statistical office. There were recorded the data for each month of the year. The indicators of unemployment were expressed in their absolute numbers. Unfortunately, the rate of unemployment, however, was not created. As announced by the Czechoslovak Statistical Office, the methodology of the calculation of people's unemployment was changed in 1925. The data related to the all the Czechoslovakia (Czech, Moravia, Silesia, Slovakia and Ruthenia).

In the paper there will be the similar procedures used as it was used together with my university colleagues in the latest monography, along with in the latest paper published in Ostrava (Slavata 2015). In my latest paper, I described a comparison of the database describing the regional housing markets of Czech Republic with the regional rates of unemployment.

There will be data recorded with respect to the research questions investigated. The steps in accordance with theoretical literature (Albright, Winston 2015) will be taken.

The steps:

1. Descriptive statistics, where will be the initial level of the real estate market presented. The main purpose is to obtain the general view on the real estate market situation during the 20 's and 30 's of the $20^{\text {th }}$ century.

2. Identification of the main relationship of variables.

3. The estimation of data by the ordinary least squares (OLS)

For the second step of the analysis and according to many researches, the Pearson correlation coefficient is suitable to estimate the basic relationship. I do expect the linear relationship between the selected variables, which is the main limitation of the form of relationship. In this step, the relationship between the segments of the real estate market structure and unemployment will be searched. The formula for $r$ (Pearson correlation) is given by Equation (1). It is a sum of products in the numerator, divided by the product sxsy of the sample standard deviations of $\mathrm{X}$ and $\mathrm{Y}$. This requires a considerable amount of computation, so the software usually computes correlations. In this case, the Excel software will be used. The mathematic formulation is: 


$$
r=\frac{\sum_{i=1}^{n}\left(x_{i}-\bar{x}\right)\left(y_{i}-\bar{y}\right)}{\sqrt{\sum_{i=1}^{n}\left(x_{i}-\bar{x}\right)^{2} \sum_{i=1}^{n}\left(y_{i}-\bar{y}\right)^{2}}}
$$

The third, the statistical significance of the collecting data further the analysis of variance (ANOVA) will be in order to analyse the differences between the group means and their associated procedures used. The data will be by OLS model estimated. The model of a simple linear regression will be used to predict the possible situation. The basic formula can be written as:

$\mathrm{Y}=\mathrm{a}+\mathrm{bX}$

where $\mathrm{Y}$ is a predicted value from value $\mathrm{X}$. In this sample, $\mathrm{Y}$ represents the share of real the estate market segment. $X$ represents unemployment in its absolute number. $b$ is the slope of the predicted line. $\mathrm{b}$ means the change in $\mathrm{Y}$ when $\mathrm{X}$ increases by one unit.

$b=\frac{\sum\left(X_{\mathrm{i}}-\bar{X}\right)\left(Y_{\mathrm{i}}-Y\right)}{\left(X_{\mathrm{i}}-\bar{X}\right)^{2}}$

From the formula (3), you can see that it is closely related to the correlation between $\mathrm{X}$ and $\mathrm{Y}$. Specifically, if the standard deviations of $X$ and $Y$ are kept constant, the slope $b$ of the least squares line varies directly with the correlations between the two variables.

$a=Y-b \bar{X}$

The effect of the formula a (4) is not quite as interesting. It simply forces the least squares line to go through the point of the sample mean.

For the estimation of data, the Excel software will be used. The results will be presented in the next chapter of this paper.

\section{Results and Discussion}

The development of the real estate market segments during the 20 's and $30^{\prime}$ s of the $20^{\text {th }}$ century is shown in the next figure (Figure 1). The lines represent the share of the given real estate market segments from the all adverts related to the real estate market during the period. The most significant is the progress of the flats ready for the rent segment. While in 1919 it covered only $6 \%$ (see Table 1) of all the market, in 1937 it became, of course with some fluctuations, the largest segment. The segment of family houses for sell fluctuates between $10 \%$ and $37 \%$ with its share in 1937 (see Table 1). The segment of Farmhouses during the period decreases, with the significant fluctuation in 1928. The residential houses for sale look relatively stable with its significant increase at the end of the period. 
Figure 1: The structure of the real estate market of the $20^{\prime}$ s and $30^{\prime}$ s, of the $20^{\text {th }}$ century

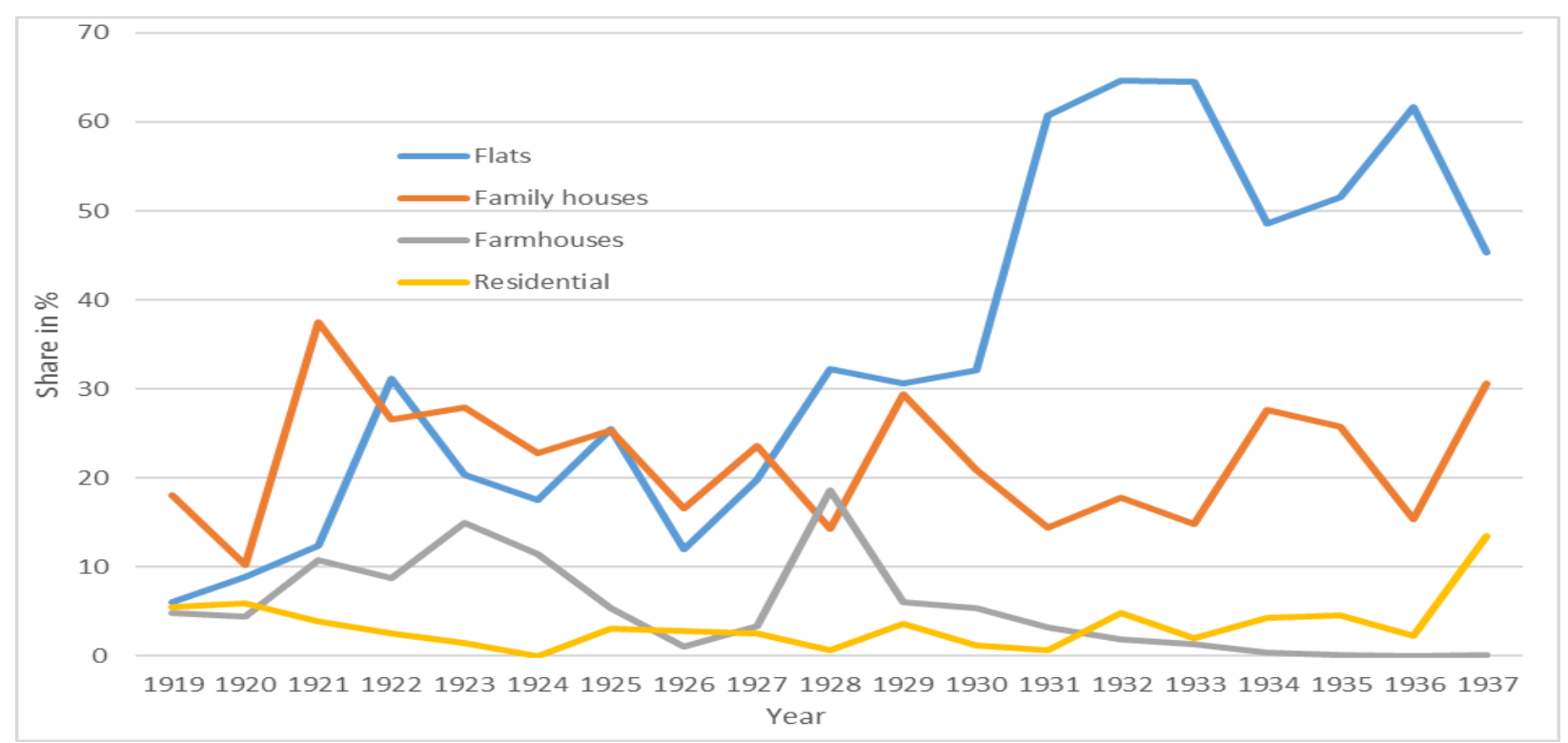

Source: own processing, Lidové noviny from the 20's and 30 's of the 20th century

The descriptive statistics provides a more specific view (see Table 1). The segment of flats for rent is the most fluctuant with a standard deviation of 19,88 in comparison to other segments of the real estate market. Residential buildings for sale are less fluctuant as it can seen be from Table 1. The residential segment of the market in comparison to the others is the lowest.

Table 1: Descriptive Statistics

\begin{tabular}{llllllll}
\hline Variable & $\begin{array}{l}\text { Num. } \\
\text { data }\end{array}$ & Mean in \% & Min in \% & Year & Max in \% & Year & St. Dev. \\
\hline $\begin{array}{l}\text { Flats } \\
\text { Family }\end{array}$ & 906 & 33,99 & 6,02 & 1919 & 64,64 & 1932 & 19,88 \\
houses & 602 & 22,14 & 10,29 & 1920 & 37,55 & 1921 & 7,06 \\
Farmhouses & 125 & 5,39 & 0 & 1936 & 18,61 & 1928 & 5,31 \\
Residentials & 94 & 3,44 & 0 & 1924 & 13,47 & 1937 & 2,94 \\
Unempl. & 114 & 26,95 & 1,64 & 1928 & 73,85 & 1933 & 26,14 \\
\hline
\end{tabular}

Notes: The minimal and maximal indicators of unemployment are in their natural logarithmic form in 10 thousands

The Pearson correlation will be used to explore the relationship between the variables. The results of the relationship analysis are indicated in Table 2. The results show a positive correlation between unemployment and the share of the rental sector $(0,80)$. There was even a negative correlation between unemployment and the share of the farmhouse sector $(-0,54)$. On the other side there was a negative correlation between the rental and farmhouse sector indicated $(-0,46)$ and farmhouse and residential sector as well $(-0,44)$.

The most significant correlation was determined in the relationship between unemployment and flats for sale (the rental sector). There is no linear correlation between unemployment and home ownership (family houses for sale). It looks like the landlords are much more dynamic in renting than homeowners in their selling. The reasons why are discussed in the next chapter of the paper. The negative correlation between unemployment and farmhouses for sale can be surprising and it will be explained in the discussion, too. 
Table 2: The Pearson Correlation Coefficient Analysis

\begin{tabular}{|c|c|c|c|c|c|}
\hline & Unemployment & Flats & Family Houses & Farmhouses & Residential \\
\hline Unemployment & 1 & & & & \\
\hline Flats & 0,803602487 & 1 & & & \\
\hline Family Houses & $-0,051278293$ & $-0,18547$ & 1 & & \\
\hline Farmhouses & $-0,540696812$ & $-0,46463$ & 0,148841841 & 1 & \\
\hline Residential & 0,205086727 & 0,034905 & 0,280258713 & $-0,442366825$ & 1 \\
\hline
\end{tabular}

Source: own processing.

Notes: ***, ** and * symbols imply statistically significance at the level of $1 \%, 5 \%$ and $10 \%$ respectively.

To investigate in detail the existence of relationship, a dynamic econometric analysis is going to be performed in the next section. As the third step in the analysis, the results of the regression model OLS are presented.

According to the OLS regressions the relationship is implied in some variables (see Table 3). Some of the variables are estimated significantly. The results reveal that the rental sector share (flats ready for sale) increases if unemployment rises. For the visual imagination, see Figure 2. On the other side, the OLS model shows that the farmhouse sector share decreases if unemployment rises.

Table 3: OLS Estimation Results

\begin{tabular}{lllll}
\hline Dep. Var. & Unempl. & Constant & R-Square & F-Stat \\
\hline Flats & $0,611^{* * *}$ & $17,51 * * *$ & 0,64 & $30,99 * * *$ \\
Family houses & $-0,13$ & 22,48 & 0 & 0,04 \\
Farmhouses & $-0,1 * *$ & $8,35 * *$ & 0,29 & $7,02 * *$ \\
Residential & 0,023 & 2,82 & 0,04 & 0,74 \\
\hline
\end{tabular}

Source: own processing.

Notes: ***, ** and * symbols imply statistically significance at the level of 1\%, 5\% and $10 \%$ respectively.

The OLS estimation results show that the relationship between the share of the rental sector and unemployment, the linear regression relationship with its $\mathrm{R}$ - square can be justified from $64 \%$. Similarly, the relationship between the share of the farmhouse sector and unemployment can be justified from $29 \%$. The statistical significance of the first relationship is at the level of $1 \%$ or $5 \%$ of the second relationship respectively.

There were not founded any relationships between the homeownership sector (the share of family houses ready for sale), the residential sector (the share of residential buildings ready for sale) and unemployment. 
Figure 2: The relationship between unemployment and the rental sector share

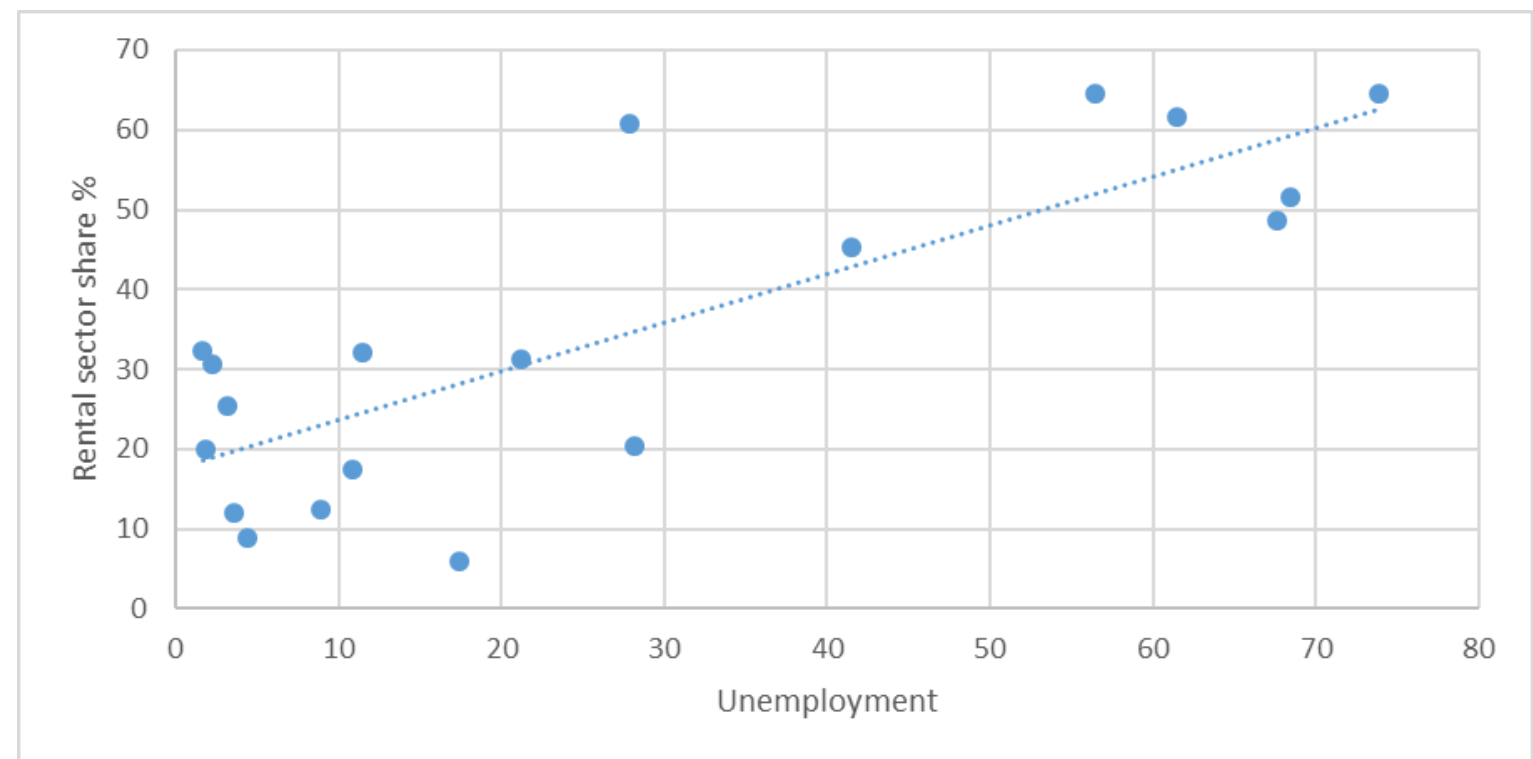

Source: own processing.

Note: Unemployment in 10th thousands shown

Based on my studies, the given relationship between unemployment and the share of the rental sector has not been presented in literature yet. The new findings can open new challenges. I would mention some explanations of new findings according to the search question announced in the previous chapter.

1. Does unemployment affect the share of the homeownership sector (family houses ready for sale)?

Unemployment does not affect the share of home ownership as the OLS analysis shows. There are some reasons for such findings. In accordance with the theoretical explanation defined in the first chapter, there are many motivation factors for home owners to offer their house for sale. There are highly motivated sellers and future sellers who are testing the market price. Even the main reason why highly motivated sellers want to sell their homes may not lie in the fact that they lost their jobs. If there are some sellers who want to sell their homes because they lost their jobs, there is possibly no motivation to sell it immediately. The expected increase of home prices can motivate the homeowners not to sell but wait and make the future profit.

On the other side, perhaps they prefer first to look for the job within the area where their homes are situated, which will take some time before they resign. Due to Oswald's postulates (1997), if they assume that the marginal costs of finding a new job are lower than the transaction costs of selling their homes (including the appreciation of property), then they are not motivated by immediate sales because they lost their job.

For the second group of the sellers (future sellers) there is of course no relationship between the unemployment and publishing of advert. There are many reasons why prospective sellers are interested to know the price of their houses. Moreover, if there is a heterogeneous market of homes, there is a very complicated situation how to determine the market price. Market research is the cheapest way to determine the market value of the house.

2. Does unemployment affect the share of flats for rent (flats ready for rent)?

A quite interesting relationship was indicated between the share of the rental sector and unemployment. In the worldwide literature, I have not found anyone who has studied this kind of relationship. The relationship seems to be highly significant (see Table 3, Figure 2). 
There is a likely explanation of the relationship:

1. Expected increase of unemployment

2. Increase of Immediate termination of the rental contract

3. Time delays

The analysis shows that an increase of unemployment causes the increase of share of flats for rent. The landlords seem to be very sensitive to the employment indicators. It is clear, that the increase of unemployment can reduce the landlord's profit. The increase of unemployment can possibly result in a rent pay risk and decrease of rents. In such a situation, the landlords increase the offers of flats ready for rent to ensure the expected decrease of rents due the increase of unemployment.

Increasing the supply of apartments ready for rent is even supported by tenants who have lost their jobs, and because they had to immediately leave the rented apartments. Obviously, landlords immediately publish the adverts for the flats for rent. That is the description of the situation when an increase of the share of supply of flats compared to all real estate is ofered. Some of the landlords may not register the expecting increase of unemployment. They can easily expect to get the same amount of rent for the flat as they got from the previous tenant. During the period, they offer the flat for the same rent until they find that the asking rent is too high. The potential tenants who compare the asking rent with the current salary are not willing to pay and refuse the flat. Such a situation forces the landlord to decrease the asking rent and increases the probability of renting the flat. During the period the cumulation of flats increases the total amount and increases the share of flats ready for rent to the all real estate market.

It is much clearer in comparison to the home owner sector, that in the rental sector, (landlords' and tenants') behaviour is highly motivated by the potential profit. Tenants compare the asking rent with the expected salary. If the salary decreases, or the rent increases, then the total utility of the tenant decreases and the tenant starts to look for a new apartment. On the other side, the landlord must cover the expenses and is forced to the most effective and profitable situation.

3. Does unemployment affect the share of farmhouses ready for sell?

The OLS model indicated the negative relationship between farmhouses ready for sell and unemployment. If unemployment increases, the share of farmhouses ready for sale to all real estate market decreases. It looks like very logical, never explained relationship.

If unemployment increases the possible alternative to the lost job then the farming comes. The farming possibly ensures a minimal income to the families during the time of high unemployment, which results into the decrease of the share of farmhouses ready for sale to the all real estate market. During the period of unemployment decrease, the farmers are willing to sell their farmhouses. There was an interesting negative relationship indicated between the share of flats ready to rent and the share of farmhouses ready to sell.

The Table 2 shows that there is a negative correlation. If the share of flats ready for rent decreases, the share of farmhouses, ready for sale increases. The likely reason even confirms the theoretical deductions describing the situation in the relationship between unemployment and the share of flats ready for rent.

It seems like some tenants who lost their jobs, decide to come back to their family farms, where a certain level of income is ensured. The share of vacant flats for rent increases, the share of farmhouses for sale decreases, because there is no motivation for sale. It ensures the family members against the risk of unemployment. 
4. Is there any relationship between the searching segments of the real estate market?

Table 2 shows another interesting correlation. There is a negative correlation indicated between farmhouses ready for sale and residential buildings ready for sale.

The likely reason to explain the relationship consists in investment decisions. These types of properties can be used for investing. There are many reasons why investors make such decisions. For instance:

1. Increase of unemployment

2. Protection of tenants

3. Expecting increase of rural land price

At the time, when the economic conditions do not allow the appropriate rate of profit the investors are willing to sell and convert the capital to the more profitable activity. So in our case, the investors convert the ownership of residential buildings into the ownership of farmhouses and conversely.

\section{Conclusion}

The main results of the paper confirm the relationship between the rental sector (flats ready for rent), the farmhouse sector (farmhouses ready for sell) and unemployment. Significant correlations and relationships were discovered. As the source for constructing the OLS model, there were the data from the daily newspaper from the 20's and 30's of the 20th century used.

The main results of research are:

1. It was found out that there is no relationship between the family houses ready for sale and unemployment.

2. It was found out that there is a significant relationship between flat ready for rent and unemployment.

3. It was found out that there is a relationship between farmhouses ready for sale and unemployment.

4. It was found out that there is a relationship between farmhouses ready for sale, flats ready for rent and residential buildings ready for sale.

The econometrical OLS model confirmed all the findings. The new findings can be used to analyse the processes in real estate practise. It may explain some behaviour of entities involved in the real estate market.

All the data were taken from old newspapers issued in the 20 's and 30 's of the 20th century. Thanks to the new IT technologies the new findings were discovered. The analysis even showed that in the first half of the 20th century the behaviour of bodies involved in the real estate market was dynamic.

The study even confirmed that the published adverts have its own logical structure reflecting the real situation on the real estate market, despite the first view, that there is no logical structure. The research even discovered the new challenges for further research. Many of interesting sources of data still wait for the analysis. The econometrical model can be used. It looks like the unknown universe with billions of stars still wait for new discoveries.

\section{Thanks}

Many thanks to Denisa Adamcová for taking the time devoted to seeking new challenges. 


\section{References}

[1] ALBRIGHT, S. CH. and W. L. WINSTON, 2014. Business Analytics. USA: Cengage Learning. ISBN 9781133629603.

[2] BAAR, N., 1998. The Economics of Welfare State. Stanford: Stanford University Press. ISBN 80-7201-017-4.

[3] HUGHES, G. and B. MCCORMICK, 1991. Housing Markets, Unemployment and Labour Market Flexibility in the UK. European Economic Review. Vol. 31, pp 83-114.

[4] IOANNIDES, Y. M. and J. E. ZABEL, 2008. Interactions, Neighborhood Selec-tion, and Housing Demand. Journal of Urban Economics. Vol. 63, pp. 229-252.

[5] JANASOVÁ, E., D. SLAVATA a J. ARDIELLI, 2014. Specifikace míry kapitalizace vybraného segmentu realitního trhu. Ostrava: VŠB-TU. ISBN 978-80-248-3670-6.

[6] MUNCH, R. J., M. ROSHOLM and M. SVARER, 2007. Home ownership, job duration, and wages. Journal of Urban Economics. Vol. 63, pp. 130-145.

[7] OSWALD, A. J., 1999. The Housing Market and Europe's Unemployment: A Non Technical Paper. Working Paper. Warwick: Working Paper Series.

[8] POLAKOVA, O., 2006. Bydlení a bytová politika. Praha: Ekopress, ISBN 80-86929-035.

[9] ROSEN, K. T. and L. B. SMITH, 1983. The price-adjustment process for rental housing and the natural vacancy rate. American Economic Review, Vol. 73, pp. 779-786.

[10] RAKOSNIK, J., 2008. Odvrácená tvář meziválečné prosperity. Nezaměstnanost v Československu v letech 1918 - 1938. Praha: UK v Praze, ISBN: 978-80-246-2817-2.

[11] SEKANINA, M., 2004. Kdy nám bylo nejhůře? Hospodářská krize 30. let 20. století v Československu. Praha: Libri, ISBN 80-7277-213-9.

[12] SIVITANIDES, S. P., W. C. WHEATON and G. R. TORTO, 2003. Real Estate Fundamentals and Asset Pricing. The Journal of Portfolio Managament. Special Issue, pp. $45-53$.

[13] WHEATON, W. C. and G. R. TORTO, 1988. Vacancy Rates and the Future of Office Rents. Real Esttae Economics, Vol 16, pp. 430 - 436.

[14] SLAVATA, D. The Ownership Structure of Housing Market and Unemployment in Czech Republic. 2015 Public Economics and Administration: proceedings of the 11th international scientific conference : Ostrava, Czech Republic, 8th-9th September 2015, VŠB - Technical University of Ostrava, pp. 185-190, ISSN 1805-9104, ISBN 978-80248-3839-7. 